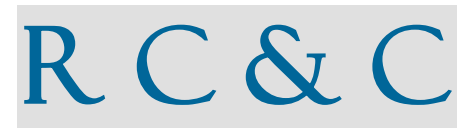

\title{
EVIDÊNCIAS DOS ATIVOS INTANGÍVEIS NO CONTEXTO BRASILEIRO: REPRESENTATIVIDADE, CARACTERIZAÇÃO, PERCEPÇÃO DE MERCADO E DESEMPENHO
}

\section{EVIDENCE OF INTANGIBLE ASSETS IN THE BRAZILIAN CONTEXT: REPRESENTATION, CHARACTERIZATION, MARKET PERCEPTION AND PERFORMANCE}

Recebido em 11.12.2014 | Aceite final em 26.09.2015 |

Nota: este artigo foi aceito pelo Editor Jorge Eduardo Scarpin e passou por uma avaliação double blind review

A reprodução dos artigos, total ou parcial, pode ser feita desde que citada a fonte.

\section{JOSÉ GLAUBER CAVALCANTE DOS SANTOS}

Bacharel em Ciências Contábeis pela Universidade Federal do Ceará - UFC I Mestrando em Administração e Controladoria pela Universidade Federal do Ceará - UFC | Rua Oscar França, 2279, Bom Jardim, CEP: 60.540-375, Fortaleza - Ceará | Telefone: (85) 87083283 / (85) 99354073 | E-mail: jglauber_cont@hotmail.com |

\section{RESUMO}

O presente estudo propositou demonstrar um perfil, mesmo que abrangente, de todos os ativos de natureza intangível divulgados nos relatórios contábeis das maiores companhias de capital aberto brasileiras. O contorno aludido compreende quatro perspectivas: representatividade do investimento intangível, qualificação da informação, percepção do mercado e relacionamento com desempenho econômico. O grupo de análise foi apontado pelo ranking da Revista Exame Melhores e Maiores (2013). Descritiva, documental, munida de abordagem quali-quantitativa, a pesquisa recorre à análise de conteúdo das notas explicativas das empresas, aplicados testes comparativos de médias não paramétricos (Mann-Whitney Test) e análise de correspondência (Anacor). A avaliação abarcou 100 observações com dados impetrados referentes ao ano-base de 2012. Com as inferências obtidas, permitiu-se suportar as seguintes evidências de pesquisa: (i) Os recursos intangíveis consomem representativa participação no patrimônio das empresas, com elevada discrepância dos níveis de investimento e divulgação; (ii) Específicos tipos de ativos intangíveis têm evidenciação sobressaída nas empresas e, ao 
mesmo tempo, absorvem elevados montantes de investimento (marcas e logos, ágios/goodwill, carteiras de clientes, fornecedores e distribuição, fidelização/exclusividade, contratos de concessões) demonstrando uma relevância informacional e patrimonial do grupo; (iii) $\mathrm{O}$ valor de mercado apresenta-se, em média, cerca de quatro vezes do valor contábil, o que poderia sinalizar reflexos do agrupamento intangível da percepção do investidor; (iv) Estabeleceu-se, além de uma distinta média de desempenho em relação a maiores graus de intangibilidade, uma associação entre este e aquele construto, sinalizando-se talvez a reversão dos retornos decorrente do aporte informacional intangível, ou o impacto do retorno positivo nas expectativas do mercado.

Palavras-chave: Intangibilidade. Informação Intangível. Vantagens Competitivas.

\section{ABSTRACT}

The present study aims to demonstrate a profile, even though ample, of all the assets of intangible nature that are disclosure in standard statement of large Brazilian public companies. The lineament referents realize four perspectives: the representativity of intangible investment, qualification of information, perception of market and relationship with economic performance. The group of analysis was appointed by ranking of Magazine Exame Melhores e Maiores (2013). The research is descriptive, documental with quali-quantitative approach, and appeal to content analysis of notes related standard statement of the companies, applying comparatives tests of mean non-parametric (Mann-Whitney Test) and correspondence analysis (Anacor). The evaluation considers 100 observations with data referents to year-base 2012. The inferences obtained permitted support the following evidences of research: (i) The intangible resources consume representative participation in property of companies, with elevated discrepancy of investment and disclosure levels; (ii) Specifics types of intangible assets have high disclosure in the companies and, at the same time, absorb a great value of investment (brand and logos, agio/goodwiil, client portfolio, suppliers and distribution, fidelity/exclusivity, contracts of concessions) demonstrating an informational and patrimonial relevancy of the group; (iii) The market value presents, in average, about four times of the accounting value, it could signalize reflexes of grouping intangible of investor perception; (iv) It was stablished, beyond a distinct mean of performance in relation the larger degrees of intangibility, an association between this and that construct, signaling, maybe, a reversion of the returns deriving of the intangible informational contribution, or the impact of positive return in the market expectations.

Keywords: Intangibility. Intangible information. Competitive advantages. 


\section{INTRODUÇÃO}

Lançando-se um olhar minucioso à conjuntura organizacional moderna, depreende-se que o eixo econômico basilar responsável pela verticalização do posicionamento da firma na busca por desempenho destacado substancia-se no capital com natureza intangível. Kayo et al. (2006) alertavam sobre a ruptura introduzida ao conceito de valor das empresas ao destacarem como ascendente $o$ interesse de investidores nos ativos intangíveis, importantes na construção de valor econômico. Novas fontes para a criação de valor emergem constantemente, sob taxas de celeridade cada vez mais elevadas. Assim, nesse contexto econômico, as vantagens pertencem não mais àquelas firmas com parques fabris vultosos, mas àquelas que maximizam a administração dos recursos intangíveis inerentes às organizações (STEWART, 1998; LOW; KALAFUT, 2003). Conforme Barney (1991), o capital intangível detém características como a raridade, a difícil imitação e substituição, que definem a vantagem competitiva.

Perez e Famá (2006a) definem os ativos intangíveis como recursos singulares, dotados de características idiossincráticas potencialmente permissivas à diferenciação e consecução de vantagens competitivas. Confere-se aos ativos intangíveis, majoritariamente, a riqueza gerada pelas empresas (desempenhos econômicos superiores e criação de valor para o acionista) e as discrepâncias entre valor de mercado e valor contábil (ativos intangíveis não reconhecidos).

Deste modo, concomitantemente, seria um tanto quanto lógica a previsão do aparecimento de demandas informacionais específicas, coerentes com a relevância econômica atribuída aos ativos intangíveis. O problema, todavia, reside na compreensão de que, segundo Lauretti, Kayo e Marçal (2009), as informações contábeis não refletem integralmente o valor do intangível. Como corrobora Sallaberry (2014, p. 13), mesmo depois de "agregarem valor às empresas [...] a valoração dos ativos intangíveis é complexa".

De maneira colaborativa, Meneses, Ponte e Mapurunga (2013, p. 143) depõem que "a complexidade da identificação e da mensuração dos ativos intangíveis culmina na necessidade de evidenciação de informações atinentes aos critérios utilizados". Retornando ao raciocínio exposto por Lauretti, Kayo e Marçal (2009), concluiu-se que o valor das empresas extrapola a parcela tangível dos recursos, voltando-se para capacidade de criação de valor, à rentabilidade futura e perspectivas de crescimento, variáveis, por assim dizer, puramente intangíveis.

Ao stakeholder, faz-se indispensável o relato informacional que ultrapasse o horizonte imposto pela forma contábil dos relatórios. O imperativo em questão reclama informações que propiciem ao usuário da informação contábil conferir valor aos ativos intangíveis, assertam os autores Lauretti, Kayo e Marçal (2009). Não à toa que Meneses, Ponte e Mapurunga (2013, p. 145) retornam a essa reflexão, porque afirmam que "é indispensável o reconhecimento, nas demonstrações contábeis, de itens não facilmente identificáveis, mas que podem agregar valores maiores quando comparados a itens fixos (tangíveis)".

Todavia, não se deve desconhecer, ingenuamente, que a influência dos ativos intangíveis nas empresas e, por conseguinte, em seu valor econômico, é relativizada por características como o setor de atividade, ciclo de vida, missão da firma, concorrência, entre outros (KAYO et al., 2006). Nesta razão, acredita-se, portanto, que os níveis de investimento em ativos intangíveis, evidenciação, tipologia e intangibilidade das empresas modifiquem-se e sejam distintos.

Em suma, considerando-se os vieses patrimonial (recursos intangíveis e construção de vantagens competitivas e valor) e informacional (demanda por informação que possa trazer os prospectos de materialização dos retornos das empresas) do capital intangível, bem como sua potencial capacidade de incorporar benefícios às organizações, esta pesquisa busca responder à seguinte questão: De que forma é caracterizado o perfil dos ativos intangíveis evidenciados pelas maiores empresas brasileiras 
de capital aberto? Define-se, portanto, como objetivo geral apresentar o perfil dos ativos intangíveis evidenciados nos relatórios das maiores companhias abertas brasileiras considerando-se as prerrogativas da representatividade do recurso, caracterização qualitativa da informação, percepção de mercado e relação com o desempenho.

Foram oportunas metas específicas para se atingir com êxito o objetivo geral e, assim, responder à questão levantada. Respectivamente, pretendeu-se (i) descrever o investimento do ativo intangível e sua representatividade patrimonial no grupo das empresas consideradas; (ii) qualificar os ativos intangíveis em relação à sua divulgação e tipologia; (iii) apontar reflexos do grupo patrimonial dos ativos intangíveis das empresas na percepção do investidor ou grau de intangibilidade; e (iv) relacionar grau de intangibilidade e desempenho nas empresas.

Penrose (2006, p. 67) destaca que, "em geral, as decisões financeiras e de investimento das firmas são controladas por um desejo de aumentar os lucros totais a longo prazo". Logo, a tomada de decisão do stakeholder será subsidiada pela melhor previsão de sobrevivência e de continuidade, sustentada pela absorção de diferenciação e vantagens competitivas da firma. E, levando-se em consideração a contribuição que possui a informação intangível, nesse sentido, investigar o perfil evidenciado do capital não tangível pode ser relevante. Além disso, mostra-se no trabalho de Mazzioni et al. (2014) que esta discussão não interessa apenas a um só grupo informacional, mas a variados interessados, o que demonstra a relevância deste debate. E com todas essas ponderações o presente estudo encontra justificativa para sua realização.

\section{FUNDAMENTAÇÃO TEÓRICA}

A discussão em torno da lógica econômica das firmas regida pela economia dos ativos intangíveis, bem como seu reflexo na estrutura das organizações, possui, genericamente, duas principais perspectivas: (i) aquela que compreende as potenciais vantagens da absorção desse tipo de recurso pela organização; e (ii) também aquela que se refere ao impacto informacional do reconhecimento do capital intangível na empresa. Assim, finca-se nesses dois prismas de discussão todo o debate que substancia o questionamento emergente a esta pesquisa.

\subsection{ATIVOS INTANGÍVEIS E A BUSCA POR VANTAGENS COMPETITIVAS}

O patrimônio intangível adquiriu significativa contribuição econômica para as firmas modernas, porque conhecimento e informação ganharam status de essencialidade na posição de ativos das empresas no desenvolvimento de estratégias que contemplem os horizontes de longo prazo. A resposta para a importância atribuída aos ativos intangíveis é simples, porém dotada de conceitos intrínsecos complexos, como se vê em Kayo et al. (2006, p. 77): "a posse de recursos valiosos, raros, inimitáveis e insubstituíveis pode levar à geração de lucros anormais que, em última análise, é responsável pela formação do valor da empresa".

Como notado pelo exposto, o viés argumentativo sobre a contribuição do patrimônio intangível à organização tem regência no seguinte entendimento: patentes, marcas, softwares, know-how, entre outros, agregam valor, pois são fontes primárias de vantagem competitiva. A essa razão, Teh, Kayo e Kimura (2008) expõem que o gerenciamento adequado do intangível é substancial à maximização da riqueza dos acionistas. Acrescenta-se ainda que com obtenção de vantagens competitivas sustentáveis, originárias do patrimônio intangível da empresa, são erguidas barreiras contra várias ameaças competitivas. 
Imediatamente seguinte aos conceitos de gerenciamento do intangível e construção de barreiras concorrenciais, outro conceito emergente relaciona-se à sinergia deste ativo. Como é empregado por Kayo et al. (2006) e Colauto et al. (2009), a determinação do valor do capital não material perpassa, necessariamente, pelo contexto estratégico da firma, visto que um ativo de natureza intangível não gera valor em segregado, porque é preciso interação com os demais recursos da empresa, principalmente os intangíveis.

Villalonga (2004) assegura como questão fundamental às estratégias corporativas a reflexão em torno das diferenças de desempenho das organizações. Em seu estudo, viu-se que essas distinções podem ser atribuídas, também, a ativos intangíveis, pois eles trazem proteção contra desvantagens persistentes no mercado. Convergentemente a Villalonga (2004), Ritta e Ensslin (2010) mostraram que os ativos intangíveis teriam capacidade de acrescentar receitas, adicionar valor ao patrimônio líquido e propiciar valorização às ações em grupo composto de 47 companhias com maior volume financeiro na BM\&FBovespa.

No momento em que Machado e Famá (2011, p. 91) defendem que o enfrentamento de ambientes altamente competitivos "faz com que as companhias dediquem esforços para gerir da melhor forma possível seus ativos intangíveis", reforçam-se as inferências constatadas nas investigações de Perez e Fama (2006a; 2006b), Teh, Kayo e Kimura (2008), Lauretti (2011) e Sallabery (2014) - ativos intangíveis reconhecidos e não reconhecidos, resguardadas todas as especificidades metodológicas das pesquisas, podem explicar o desempenho das empresas. Sem dúvidas, compreender a forma como ativos intangíveis criam valor à empresa permite entender os efeitos deslocados ao desempenho da firma (LAURETTI, 2011).

Por outro lado, apesar dessas evidências favoráveis, Kayo, Patrocínio e Martin (2009, p. 67), mesmo reforçando que "alguns estudos sugerem que quanto mais intangíveis os recursos adquiridos, maior o valor criado", não constataram evidências acerca do exercício da intangibilidade como agente influente da criação de valor, em aquisições de negócios.

Verdadeiramente, dispõe-se deveras importante aos diversos stakeholders entender de forma oportuna os fatores críticos que interferem na tomada de decisão. Mostra-se óbvio que, se a economia suportada pelo conhecimento evoluiu e os métodos voltados para a criação de valor transferiram-se ao capital intangível, diferente do capital tangível, compreender os reflexos dessa mudança provoca interesse para discussão do futuro econômico das firmas (TSAl; LU; YEN, 2012).

Destarte, pôde-se depreender, diante dessa abreviada explanação construída, que o imperativo regido pela construção das vantagens competitivas e de um cenário organizacional favorável à economia do conhecimento, à melhoria do desempenho e do valor da empresa, aqui demonstrado, habita na percepção de que o investimento no ativo intangível é a fonte do sucesso organizacional, graças às suas singularidades, origens da diferenciação. Para além do viés patrimonial, existe outra face da moeda a ser considerada: o aspecto informacional.

Em oposição à corrida pelo investimento intangível, há uma demanda por informação. Aos stakeholders, que suportam riscos decorrentes dos investimentos, não basta apenas investir, não se pode desvalorizar a informação. Além do quanto representam e como corroboram para o desempenho, espera-se saber quais, quantos e como esses recursos podem ser tão relevantes para a empresa. Eis que se configura neste ponto, portanto, o viés informacional do intangível.

\subsection{ATIVOS INTANGÍIVEIS E O VIÉS INFORMACIONAL}

Os recursos intangíveis das organizações são resultado de informação e conhecimento incorporado pelas suas atividades produtivas. Através da experiência adquirida e unificada, ao longo do tempo 
em operação e da estrutura constante à firma, capacidades diversas passam a ser construídas e acumuladas. Ao processo contábil recai toda a responsabilidade em torno da evidenciação e avaliação de tais capacidades - capital intangível (COLAUTO et al., 2009).

Lev (2001) é favorável à concepção de que os ativos intangíveis frequentemente estão associados ao incremento de retorno das firmas, mas ascende uma discussão peculiar sobre os recursos em questão. Segundo ele, evidências apontam a criação de significativa assimetria de informação relacionada ao capital não tangível.

Essa acepção assemelha-se às exposições de Himmelberg, Hubbard e Palia (1999) e Silveira e Barros (2008), que convergem na ideia de que o capital intangível possui maior dificuldade de monitoramento por ser mais facilmente desviado a fins que contrariam os interesses da firma, dificultando o controle, ao mesmo tempo em que promove o desalinhamento do interesse final atrelado ao investimento intangível - melhores desempenho e valor das empresas, atribuídos à construção de vantagens competitivas.

Assim, para se entender sobre a materialidade em potencial intrínseca à informação do capital intangível, recorre-se a uma breve reflexão. Tomando-se como contribuição a fala de Lauretti (2011, p. 30), denomina-se de informação tangível aquela "relacionada com os resultados contábeis", e informação intangível a "associada às perspectivas de desempenho". Concorda-se que gestores possuem ampla discricionariedade na construção da contabilidade e controles. Aliás, provoca-se o reforço de que a decisão tocante à informação evidenciada publicamente é responsabilidade desses gestores (SUNDER, 2014).

O questionamento iminente que recai considera a evidenciação da informação interferente na tomada de decisão de investidores [efetivos e potenciais]. Além disso, veste-a na condição de impulsionadora da liquidez dos fatores de mercado, favorável a captar recursos (SUNDER, 2014). Essa linha de raciocínio conduz uma coerente conclusão, portanto. Admitindo-se que o capital intangível investido propicia maximização do valor da empresa, então a cobrança pela divulgação deste recurso demandaria maior reforço diante de atributos como complexidade da identificação dos intangíveis, adequada valoração e previsibilidade de ganhos futuros.

Eis aqui uma dualidade condicionada ao ativo intangível das empresas: investimento financeiro versus a qualificação deste capital, provável fator que corrobora o desempenho. A literatura pertinente, segundo Arrighetti, Landini e Lasagni (2014), relata o impacto, positivo, dos ativos intangíveis em diversas métricas de desempenho, inferência observada no estudo de Basso et al. (2014). Soma-se a isso o fato do ativo intangível abranger parcela proeminente dos recursos de um grande número de empresas (KUMAR, 2013).

Quando se discute o contexto corporativo brasileiro, com o processo de harmonização da contabilidade às normas internacionais (IFRS), as investigações apresentam ainda maior necessidade de reflexão, pois foram exigidas às empresas múltiplas mudanças (CERQUEIRA et al., 2012), inclusive a incorporação, o reconhecimento e a divulgação de ativos intangíveis que, até então, com processo iniciado apenas em 2008 e compulsória a adaptação no exercício de 2010, portanto recente, não se tinham informações requeridas em relatórios contábeis.

Nesta pesquisa, em meio à relevância do debate que envolve os ativos intangíveis, sob os aspectos patrimonial e informacional, principalmente, buscou-se amplificar esse escopo de discussão, pontualmente em relação às empresas brasileiras, visto que não se encontraram estudos sobre a temática que compartilhassem de perspectiva de análise que absorvesse, ao mesmo tempo, as concepções de representatividade financeira do recurso, sua qualificação em termos de divulgação e caracterização do tipo de intangível, as possíveis relações deste ativo à perspectiva futura do mercado e interação com o desempenho. Espera-se aqui que, diante dos resultados alcançados, 
surjam evidências abrangentes da contribuição dos ativos intangíveis à estrutura das empresas brasileiras, inclusive através da sua identificação.

\section{MÉTODO DA PESQUISA}

\subsection{CLASSIFICAÇÃO DA PESQUISA, AMOSTRA E COLETA DE DADOS}

Por se debruçar à descrição do perfil dos ativos intangíveis evidenciados pelas maiores companhias abertas do Brasil, considerando-se sua representatividade patrimonial, tipologia, percepção de mercado e relacionamento com o desempenho, esta pesquisa enquadra-se como descritiva, pois conforme Collis e Hussey (2005), preocupa-se com a identificação e obtenção de características acerca de determinado problema em um agrupamento específico. Dentre as fontes de coleta dos dados demandados, encontram-se as demonstrações financeiras (Balanço Patrimonial e Demonstração do Resultado do Exercício) e Notas Explicativas das empresas, além da base Economática ${ }^{\circledR}$, com dados alusivos ao ano-base de 2012. O grupo investigado nesta pesquisa abarcou todas as 100 maiores empresas brasileiras de capital aberto apontadas pela Revista Exame Melhores e Maiores, edição de 2013.

Quanto à abordagem, para Sampieri, Collado e Lucio (2013), este estudo pode ser denominado quantitativo, visto que emprega técnicas estatísticas para tratamento e análise dos dados (Testes de Diferença de Médias e Análise de Correspondência). Ressalta-se, no entanto, o emprego da Análise de Conteúdo, técnica qualitativa, especificamente à etapa de coleta de dados. Recorreu-se a esta técnica prioritariamente à análise das Notas Explicativas (relatório que viabiliza avaliação qualitativa da informação contábil divulgada nos demonstrativos das empresas) em razão do detalhamento ativos de natureza intangível. À luz de Bardin (1977), na análise de conteúdo, informações suplementares são fornecidas ao pesquisador, que percorre as fases denominadas pré-análise (seleção do material), exploração do material (documentos), e de tratamento dos resultados (interpretação e inferência). Percebeu-se, diante da questão de pesquisa suscitada, necessidade de se percorrer extensa análise descritivo-qualitativa, anterior ao exame puramente quantitativo das variáveis estudadas. Deste modo, julga-se oportuna e pertinente a classificação do estudo como quali-quantitativo, por ser notória a aglutinação das duas abordagens de avaliação.

\subsection{DESCRIÇÃO DAS DADOS DA PESQUISA}

Para consecução das metas sugeridas, impôs-se a esta pesquisa detalhar o conjunto dos dados utilizados. Dispõe-se, no Quadro 1, evidência dessa demanda específica, constatadas adiante.

Quadro 1 - Dados da pesquisa e fontes de coleta

\begin{tabular}{|c|c|c|}
\hline Dados & Descrição dos Dados & Fontes de Coleta \\
\hline Investimento Total & Valor do Ativo Intangível & Balanço Patrimonial \\
\hline Representatividade Patrimonial & $\begin{array}{c}\text { Ativo Intangível equacionado pelo } \\
\text { Ativo Total }\end{array}$ & \multirow{2}{*}{$\begin{array}{c}\text { Balanço Patrimonial e Notas } \\
\text { Explicativas }\end{array}$} \\
\hline Tipologia dos Ativos Intangíveis & Descrição dos Ativos Intangíveis & \\
\hline Grau de Intangibilidade & $\begin{array}{c}\text { Valor de Mercado equacionado pelo } \\
\text { Patrimônio Líquido }\end{array}$ & $\begin{array}{c}\text { Economática }^{\circledR} \text { e Balanço } \\
\text { Patrimonial }\end{array}$ \\
\hline $\begin{array}{l}\text { Return on Equity (ROE) - expressa a } \\
\text { remuneração do capital próprio }\end{array}$ & $\begin{array}{l}\text { Lucro Líquido equacionado pelo } \\
\text { Patrimônio Líquido }\end{array}$ & \multirow{2}{*}{$\begin{array}{c}\text { Balanço Patrimonial e } \\
\text { Demonstração do Resultado } \\
\text { do Exercício }\end{array}$} \\
\hline $\begin{array}{c}\text { Return on Assets (ROA) - representa a } \\
\text { remuneração dos ativos }\end{array}$ & $\begin{array}{c}\text { Lucro Líquido equacionado pelo Ativo } \\
\text { Total }\end{array}$ & \\
\hline
\end{tabular}

Fonte: Elaborado pelo autor. 
Pretendeu-se a identificar os ativos intangíveis por meio da inferência acerca do nível de investimento neste grupo patrimonial, descrever sua preponderância na totalidade dos ativos, categorizá-los por tipo e verificar a participação relativa do capital intangível na estrutura das organizações, definido como grau de intangibilidade, para Kayo (2002), Perez e Fama (2006). Acerca do desempenho, empregaram-se os retornos dos acionistas e dos ativos, apontado por Assaf Neto (2010) e empregado nos estudos Decker et al. (2013) e Mazzioni et al. (2014).

\subsection{TRATAMENTO DOS DADOS E CONSECUÇÃO DOS RESULTADOS}

De posse do balanço patrimonial alcançava-se o primeiro dos objetivos específicos, por meio da descrição do investimento em ativos intangíveis e do impacto patrimonial que este tinha na composição de bens e direitos das empresas. Ao segundo dos objetivos específicos a análise de conteúdo foi substancial, porque através das informações qualitativas expressas nas notas explicativas extraia-se a tipologia desses ativos e a evidenciação dos mesmos. O terceiro dos objetivos específicos foi contemplado em dois momentos. De início, pela avaliação descritiva do grau de intangibilidade, com a coleta do valor de mercado das empresas (preço de todas as ações negociadas pela empresa multiplicado pela respectiva quantidade dessas ações, obtido no banco de dados Economática ${ }^{\circledR}$ ). Em seguida, pelo comparativo do investimento relativo dos intangíveis em relação ao grau de intangibilidade (Teste de Mann-Whitney). Esse mesmo comparativo foi realizado com as medidas de desempenho (ROE e ROA) em relação ao grau de intangibilidade, desta vez em atenção ao último dos objetivos específicos. O Teste de Mann-Whitney (não paramétrico) se faz necessário, conforme Fávero et al. (2009), quando se pretende comparar determinada variável (na pesquisa: (i) preponderância do intangível no patrimônio; (ii) e desempenho), em grupos distintos, onde se constata violação da hipótese de normalidade das variáveis. Como critério de segregação dos grupos, estabeleceu-se a mediana do grau de intangibilidade, critério de Perez e Famá (2006a). Nos Grupos " 1 " estariam as empresas com grau de intangibilidade abaixo da mediana da amostra e nos Grupos "2" as firmas com valores acima desta mediana. Com expectativas da observância de sensibilidade do grau de intangibilidade em relação à representatividade do investimento no intangível e aos desempenhos das empresas, testaram-se as seguintes hipóteses:

H1a: Existe diferença significativa nas médias não paramétricas de representatividade do ativo intangível sob o critério de segregação do grau de intangibilidade.

H1b: Existe diferença significativa nas médias não paramétricas de desempenho sob o critério de segregação do grau de intangibilidade.

O alcance do quarto objetivo específico seria completo com a análise de associação entre os dados do desempenho e do grau de intangibilidade. Nesta etapa procedeu-se com a Análise de Correspondência (Anacor) com vistas à exibição da eventual associação entre variáveis não métricas (categóricas) em um mapa percentual demonstrando a existência de qualquer padrão nos dados, como afirmam Fávero et al. (2009). Para tanto, foi imprescindível, primeiramente, a transformação das variáveis do grau de intangibilidade e do desempenho em variáveis não métricas, seguindo-se o critério dos quartis. Foi aplicado o teste Qui-quadrado, responsável à indicação (ou não) de associação entre as medidas, requisito que viabiliza a Anacor. Deste teste foi formulada a seguinte hipótese testada:

H2: Há associação envolvendo o grau de intangibilidade e o desempenho das empresas. 
Empregou-se em todas as análises estatísticas requeridas o suporte do software Statistical Package for the Social Sciences 21.0 (SPSS), estabelecendo-se nível crítico de significância ( $p$-value) 0,05 como aceitável.

\section{ANÁLISE E DISCUSSÃO DOS RESULTADOS}

\subsection{INVESTIMENTO DO ATIVO INTANGÍVEL E SUA REPRESENTATIVIDADE PATRIMONIAL NAS EMPRESAS}

A primeira etapa definida nesta pesquisa como demanda para se responder ao questionamento proposto consiste na descrição do investimento em capital intangível e sua representatividade patrimonial, primeiro dos objetivos específicos. Para tanto, a Figura 1 traz um panorama sobre os valores direcionados aos ativos intangíveis das maiores companhias abertas do Brasil.

Figura 1 - Perfil descritivo do investimento no grupo dos ativos intangíveis

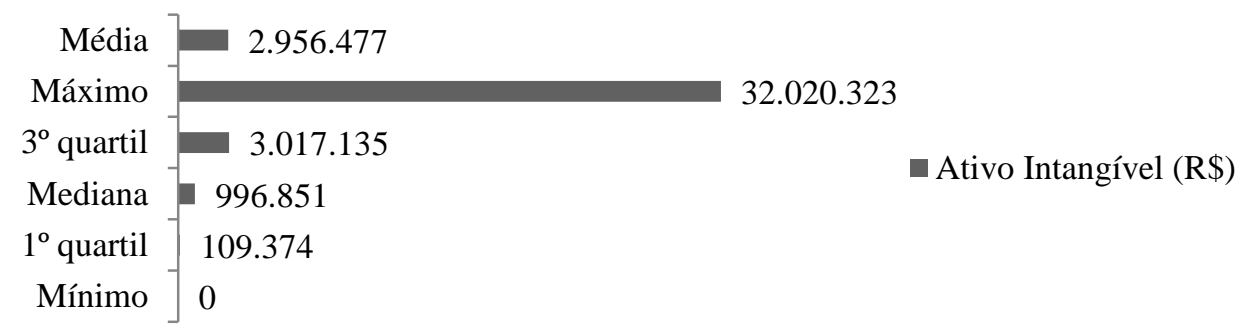

Nota: Investimentos em milhares de reais conforme notas explicativas das empresas.

Fonte: Dados oriundos da pesquisa.

Demonstra-se, na Figura 1, elevada variabilidade do investimento em ativos intangíveis. Três das empresas analisadas tiveram valor investido nulo, com média geral de $\mathrm{R} \$ 2.956 .477,00$. Vê-se que metade das empresas emprega, no máximo aproximadamente $\mathrm{R} \$ 1 \mathrm{mi}$, com valor máximo alcançando os R\$ $32 \mathrm{mi}$. Essa dispersão pode ser explicada pelas características das empresas, como setor, porte, estratégia, e outros, como afirmam Kayo et al. (2006). Ressalta-se que as rubricas de investimento, por si só, não são suficientes ao entendimento de como os ativos intangíveis impactam o patrimônio das firmas brasileiras. Destarte, a Figura 2 vem em complemento a essa evidência, pois apresenta a representatividade do investimento intangível.

Figura 2 - Representatividade patrimonial do ativo intangível nas empresas

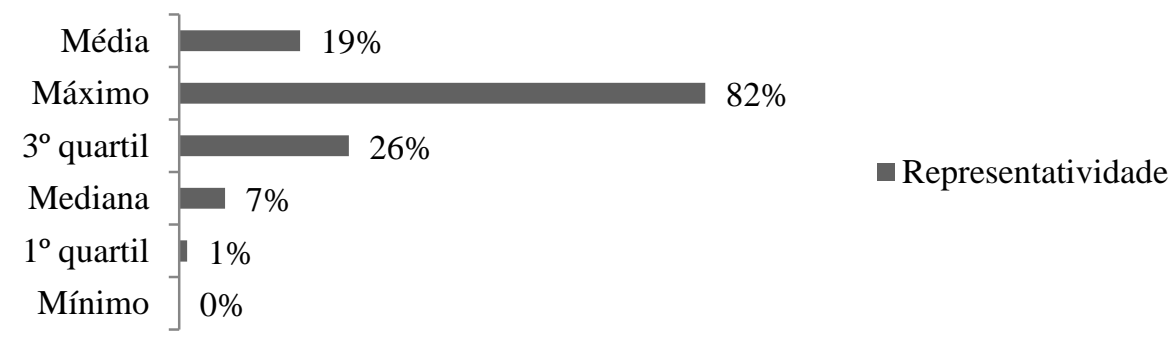

Fonte: Dados oriundos da pesquisa.

Recorda-se que a representatividade do ativo intangível fora calculada equacionando-se o seu valor pelo montante de todos os bens e direitos das empresas (ativo total). Da Figura 2, notou-se que, em 
média, o capital intangível detém relevância patrimonial, tomando-se o valor de $19 \%$ de representatividade, chegando a alcançar expressivos $82 \%$ em uma das empresas dessa amostra. Todavia, sinaliza-se uma concentração dos maiores vultos despendidos pelas firmas, visto que o terceiro quartil aponta $26 \%$ de representatividade. Em outras palavras, três de cada quatro empresas não alcançam investimentos relativos superiores a este patamar. Conclui-se que os ativos intangíveis são, na amostra em questão, representativos, porém há maior atenção ao investimento em um pequeno grupo de firmas.

\subsection{QUALIFICAÇÃO DOS ATIVOS INTANGÍVEIS: DIVULGAÇÃO E TIPOLOGIA}

O segundo dos objetivos específicos referia-se à qualificação dos ativos intangíveis. Ou seja, seguinte aos atributos do investimento e da representatividade, buscava-se saber sobre com que frequência e quais os ativos intangíveis relatados em notas explicativas.

Primeiramente, anuncia-se que se identificaram 25 diferentes categorias de ativos intangíveis, pelo presente estudo, nas notas explicativas das empresas. A Figura 3 aponta, por número de empresas, a estatística descritiva da divulgação dessas categorias.

Figura 3 - Frequência da divulgação das categorias de ativos intangíveis

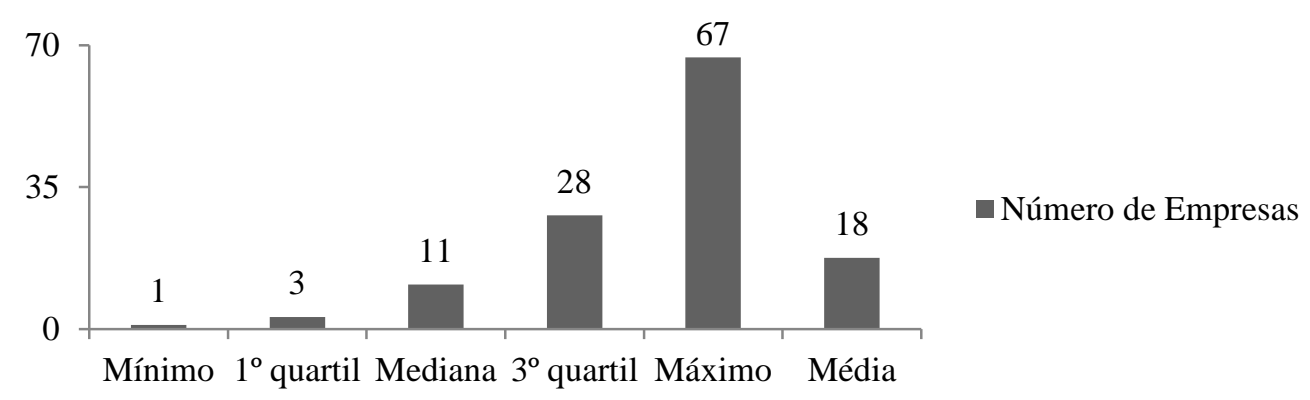

Fonte: Dados oriundos da pesquisa.

A Figura 3 demonstra como cada tipo de ativo intangível foi mencionado em relação ao total da amostra. Cada uma das 25 categorias de ativo intangível poderia ser mencionada por todas as 100 empresas analisadas. Contudo, viu-se que a maior frequência de divulgação observada pertencente à categoria ágio/deságio/goodwill, com 67 empresas divulgando-a. A ocorrência de diversas incorporações (fusões, aquisições, etc.) no contexto brasileiro pode explicar esse resultado. Metade de todas as categorias de intangíveis foi evidenciada em nota explicativa por até 11 empresas (mediana), sendo o valor médio de 18 empresas - em geral, cada ativo intangível foi referido em 18 notas explicativas de empresas diferentes. Duas categorias de recursos intangíveis foram evidenciados por apenas uma dentre todas as empresas da amostra (instalações/benfeitorias em imóveis de terceiros e sistemas administrativos). Toda essa diversificação também fora observada nos estudos de Colauto et al. (2009) e Santos et al. (2012), em relatórios da administração e notas explicativas, nessa ordem apresentada.

Agora, em relação às empresas, a Figura 4 aponta a descrição dessa divulgação, segunda fase da qualificação dos ativos intangíveis em relação à divulgação e tipologia. 
Figura 4 - Frequência da divulgação dos ativos intangíveis por empresa

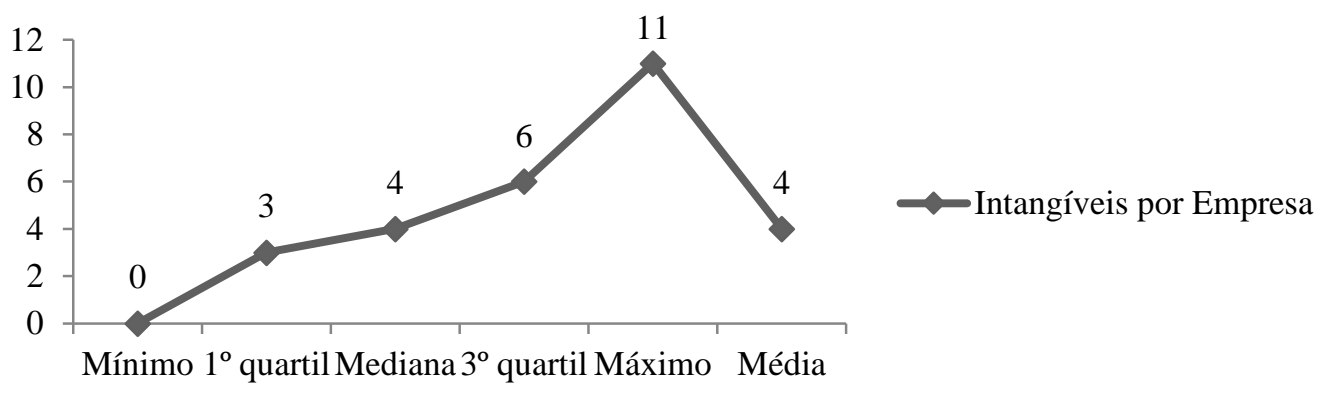

Fonte: Dados oriundos da pesquisa.

Diferentemente da discussão anterior, a Figura 4 expõe o cenário genérico da divulgação dos intangíveis em relação às empresas da amostra. Em média, as empresas evidenciaram em suas notas explicativas até 4 tipos distintos de capital intangível, sendo o máximo observado de 11 diferentes recursos empregados nas maiores empresas brasileiras. Tal dispersão sinaliza uma demanda heterogênea pelos recursos intangíveis, visto que cada atividade, por exemplo, pode requerer o investimento em ativos intangíveis específicos. Por exemplo, uma empresa do setor de tecnologia poderia apresentar prevalência do recurso "software", enquanto que empresas que se dedicam à participação em outras organizações poderiam dispor de elevados recursos em "goodwill". Realizar agrupamento dos ativos intangíveis em categorias por finalidade não foi pretensão desta pesquisa, contudo autores como Stewart (1998), Lev (2001) e Kayo (2002) propõem eventuais classificações: ativos humanos, ativos de mercado, ativos de inovação, e ativos de relacionamento, estão entre as taxonomias.

A tipologia dos ativos intangíveis evidenciados pelas empresas pode favorecer a compreensão da utilização desses recursos que são cada vez mais proeminentes nas organizações e capazes de favorecer a construção de vantagens competitivas (KUMAR, 2013; SLLABERRY, 2014, entre outros). Os Quadros 3 e 4, respectivamente, buscam a contemplação integral do objetivo específico que visa a qualificação do ativo intangível. Nos dois quadros emprega-se o limite superior do quartil para agrupamento, sendo no Quadro 3 em relação às empresas que fizeram divulgação da categoria, e no Quadro 4 os investimentos descritos nas rubricas dos relatórios.

Quadro 3 - Ativos intangíveis evidenciados em relação às empresas

\begin{tabular}{|c|c|c|}
\hline Grupos & Frequência & Ativos Intangíveis evidenciados em Notas Explicativas \\
\hline $\begin{array}{c}10 \\
\text { quartil }\end{array}$ & $\begin{array}{c}1-3 \\
\text { Empresas }\end{array}$ & $\begin{array}{l}\text { Instalações/benfeitorias em Imóveis de Terceiros; Sistema Administrativo; Banco de } \\
\text { Dados/Processos; Adiantamento a fornecedores/Despesas de comercialização } \\
\text { diferidas; Know-how (Tecnologia); Aquisição de folha de pagamento/empregados }\end{array}$ \\
\hline $\begin{array}{c}20 \\
\text { quartil }\end{array}$ & $\begin{array}{c}\text { 4-11 } \\
\text { Empresas }\end{array}$ & $\begin{array}{c}\text { Contratos de Programa (Compromisso/Invest./Crédito de carbono); Projeto de } \\
\text { Implementação de Sistemas/Processos; Sistema de Informação; Gastos com } \\
\text { Implantação de lojas/Infraestrutura; Direito ao uso de Software; Contratos de } \\
\text { Franquias/Associação/Acordos de não concorrência }\end{array}$ \\
\hline $\begin{array}{c}30 \\
\text { quartil }\end{array}$ & $\begin{array}{c}12-28 \\
\text { Empresas }\end{array}$ & $\begin{array}{l}\text { Pontos Comerciais/Fundo de Comércio/Redes de polo; Direito de Uso/Exploração } \\
\text { (reserva, minério, água); Licença de uso de Software; Direitos e Licenças de uso } \\
\text { (diversos); Desenvolvimento de intangíveis/produtos/outros; Patentes }\end{array}$ \\
\hline $\begin{array}{c}40 \\
\text { quartil }\end{array}$ & $\begin{array}{c}29-67 \\
\text { Empresas }\end{array}$ & $\begin{array}{l}\text { Contratos de Exclusividades/Concessões; Carteira de } \\
\text { Clientes/Fornecedores/Fidelização/Contratos de distribuição; Marcas/Logos; } \\
\text { Software; Não identificado (Outros); Ágio/Deságio/Goodwill }\end{array}$ \\
\hline
\end{tabular}

Fonte: Dados oriundos da pesquisa. 
De início, em relação à evidenciação por empresa, o Quadro 3 expõe os ativos intangíveis, em totalidade, mencionados pelas empresas em notas explicativas, extraídos mediante análise de conteúdo e leitura, na íntegra, da nota alusiva ao grupo do ativo intangível em cada empresa. Por vezes, a denominação da empresa não era esclarecedora o suficiente ao enquadramento do ativo. Assim, recorria-se às notas suplementares descritivas que diversas empresas utilizavam como subsídio informacional. Alguns intangíveis parecem característicos de grupos pontuais de empresas. A "aquisição de folha de pagamento/empregados" fora evidenciada apenas por bancos (BCO Brasil, BCO Estado do Rio Grande do Sul e Itaú Unibanco S. A.), por exemplo. Empresas do segmento elétrico, por outro lado, destacam-se na posse de concessões pela sua necessidade de direitos à exploração de recursos públicos. Nota-se que, enquanto algumas das categorias é amplamente difundida pelas empresas, outras parecem ser mais específicas, e por que não, inerentes a determinados contextos organizacionais. Para conclusão mais precisa, era preciso um cruzamento da divulgação com os setores e atividades específicas, o que não foi o foco desta proposta de estudo.

Esta pesquisa provoca ainda reflexão acerca do prejuízo informacional proporcionado devido ao reconhecimento da rubrica "outros" por um número significativo das empresas (quartil 4). A materialidade da informação contábil pode impactar a decisão do stakeholder. Não se sabe acertadamente a especificação exata deste ou destes ativos intangíveis que, para as empresas, não necessitam de evidenciação com maior grau de detalhamento. Como é notado no Quadro 4, adiante, que relaciona as categorias aos investimentos, esta rubrica encaixa-se no quartil 3 dos investimentos, o segundo mais vultoso.

Quadro 4 - Ativos intangíveis evidenciados em relação ao investimento

\begin{tabular}{|c|c|c|}
\hline Grupos & Investimento & Ativos Intangíveis evidenciados em Notas Explicativas \\
\hline $\begin{array}{c}10 \\
\text { quartil }\end{array}$ & $\begin{array}{l}24.289,00 \mathrm{a} \\
221.428,00\end{array}$ & $\begin{array}{c}\text { Adiantamento a fornecedores/Despesas de comercialização diferidas; Projetos } \\
\text { em Desenvolvimento/Concluídos; Sistema Administrativo; Sistema de } \\
\text { Informação; Know-how (Tecnologia); Projeto de Implementação de } \\
\text { Sistemas/Processos; Instalações em Imóveis de Terceiros }\end{array}$ \\
\hline $\begin{array}{c}2 \stackrel{0}{ } \\
\text { quartil }\end{array}$ & $\begin{array}{l}221.428,01 \mathrm{a} \\
2.042 .088,00\end{array}$ & $\begin{array}{c}\text { Licença de Uso de Software; Contratos de Franquias/Associação/Acordos de } \\
\text { não concorrência; Banco de Dados/Processos; Patentes; Pontos } \\
\text { Comerciais/Fundo de Comércio/Redes de Polos }\end{array}$ \\
\hline $\begin{array}{c}30 \\
\text { quartil }\end{array}$ & $\begin{array}{l}2.042 .088,01 \mathrm{a} \\
10.209 .498,00\end{array}$ & $\begin{array}{l}\text { Não Identificado (Outros); Gastos com Implantação de Lojas/Infraestrutura; } \\
\text { Direito ao Uso de Software; Aquisição de folha de pagamento/empregados; } \\
\text { Desenvolvimento de Intangíveis/produtos/outros; Direitos e Licenças de uso } \\
\text { (diversos); Software }\end{array}$ \\
\hline $\begin{array}{c}4 \stackrel{0}{ } \\
\text { quartil }\end{array}$ & $\begin{array}{l}10.209 .498,01 \mathrm{a} \\
150.859 .825,00\end{array}$ & $\begin{array}{l}\text { Marca/Logos; Direito de Uso/Exploração (reserva, minério, água); Contratos de } \\
\text { Programa (Compromisso/Invest./Crédito de carbono); Carteira de } \\
\text { Clientes/Fornecedores/Fidelização/Contratos de distribuição; Contratos de } \\
\text { Exclusividades/Concessões; Ágio/Deságio/Goodwill }\end{array}$ \\
\hline
\end{tabular}

Nota: Investimentos em milhares de reais conforme notas explicativas das empresas.

Fonte: Dados oriundos da pesquisa.

Mediante o Quadro 4, procura-se explicitar a tipologia dos ativos intangíveis conforme seus investimentos. A apresentação segue rigorosamente a proporção do investimento, de modo semelhante ao Quadro 3 (frequência de divulgação). O que se destaca em negrito é que alguns intangíveis coincidem em grupo de evidenciação e investimento. Logo, depreende-se que os recursos intangíveis de maior relevância para este grupo de firmas (divulgação e valor) são as marcas/logos, carteira de clientes ou de fornecedores, fidelização e contratos de distribuição, contratos de exclusividade ou concessões e o ágio ou goodwill. Nota-se que todos eles dizem respeito a ativos oriundos de relações com o mercado, sejam clientes, fornecedores ou partes relacionadas a 
investimentos. O caráter sinérgico próprio dessas transações parece originar os recursos idiossincráticos das firmas em questão. Sobre tal composição, o estudo de Santos et al. (2012) encontrou os intangíveis goodwill, software, marcas e patentes, destaque em termos de frequência; e os intangíveis goodwill, concessões, software e pesquisa e desenvolvimento de produto, no tocante à proporção em relação aos totais investidos, guardando assim alguma convergência com os resultados apresentados.

\subsection{REFLEXO DO ATIVO INTANGÍVEL NA PERCEPÇÃO DO INVESTIDOR}

Na teoria, o ativo intangível pode angariar benefícios à organização, mas na prática tal relação carece de discussão aprofundada, substanciada por evidências empíricas. Como tentativa de se amplificar esse debate, o terceiro objetivo específico propunha-se a explanar a intangibilidade nas empresas recorridas à análise. A métrica empregada para tal fim é o quociente do valor de mercado pelo patrimônio líquido das empresas ou capital próprio. À luz da pesquisa de Perez e Famá (2006a), quanto maior essa medida, maior a participação relativa dos intangíveis na estrutura da firma, tanto identificados, como os não identificados. A Figura 5 demonstra os resultados inferidos nesta pesquisa sobre o grau de intangibilidade.

O que faz o grau de intangibilidade demonstrar-se como variável pertinente à constatação dos efeitos do ativo intangível possui laço estreito com a discrepância entre o valor que o mercado paga pela ação e o seu valor nominal (patrimônio líquido da empresa sobre o número total das ações). Lauretti, Kayo e Marçal (2009) mostram que a variável da intangibilidade reflete as informações intangíveis (capacidade para criar valor, crescimento e rentabilidade futuras). Por outro lado, "os retornos futuros estão positivamente relacionados com variáveis contábil-financeiras de desempenho escaladas ao preço de mercado", sendo a principal delas o grau de intangibilidade (LAURETTI; KAYO; MARÇAL, 2009, p. 216). Conforme demonstrado pela Figura 5, esse resultados, específicos do contexto brasileiro averiguado, guardam consonância com as considerações presentes na literatura.

Figura 5 - Relação entre o valor de mercado e o patrimônio líquido das empresas

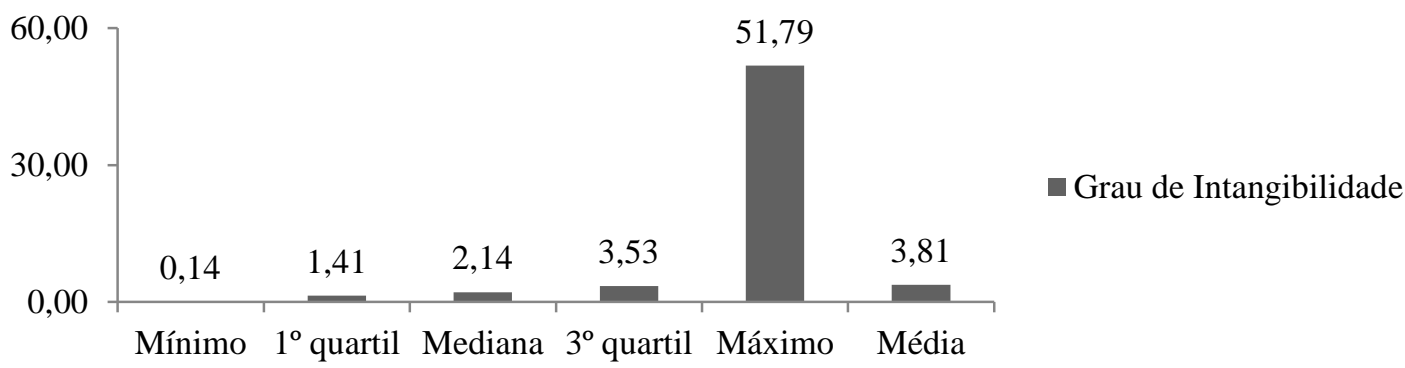

Fonte: Dados oriundos da pesquisa.

Observa-se que, com base na média, o mercado dispõe-se a desembolsar prêmio equivalente a quase três vezes o valor contábil das ações dessas empresas. Provavelmente o mercado possui informações [ou acredita possuir] que subsidiam essa supervalorização às ações (perspectivas econômico-financeiras futuras positivas, por exemplo). Se "o mercado sobrerreage ao retorno oferecido pelas ações aos investidores, independente do seu desempenho contábil", segundo Lauretti, Kayo e Marçal (2009, p. 233), então a presunção informacional também pode afetar o valor das empresas. Apenas $11 \%$ da amostra teve grau de intangibilidade menor que 1,00 , ou seja, uma 
perspectiva de mercado abaixo do valor contábil da firma; são $34 \%$ as empresas com grau de intangibilidade maior que 1,00 e menor que 2,$00 ; 26 \%$ as empresas com valor da medida de mercado entre 2,00 e 3,$00 ; 23 \%$ tinham entre 3,00 e 10,00; e $6 \%$ as empresas com valor de mercado mais de 10 vezes o seu valor contábil, chegando o máximo observado aos expressivos 51,8 , maior quociente. As últimas empresas são: "CCR S.A.", "Cielo", "Natura", "Souza Cruz", "Lojas Americanas" e a "Multiplus", respectivamente.

A fim de demonstrar se os ativos intangíveis poderiam guardar alguma relação com o grau de intangibilidade ou percepção do mercado, realizou-se o teste para comparação de médias não paramétrico de Mann-Whitney. A proxy aplicada na mediação é a representatividade do grupo de ativos intangíveis. Estabeleceu-se a mediana o critério para confronto dos dados. No Grupo 1 tinhamse empresas com intangibilidade inferior à mediana $(2,14)$ e o Grupo 2, logicamente, empresas dotadas da relação "valor de mercado/patrimônio líquido" maior que a mediana da amostra (Tabela 1). O mesmo critério fora empregado na pesquisa de Perez e Famá (2006a).

Tabela 1 - Desempenho e representatividade do intangível versus a intangibilidade

\begin{tabular}{|c|c|c|c|c|c|c|c|c|}
\hline \multicolumn{2}{|c|}{$\begin{array}{l}\text { Variável de Comparação ao Grau } \\
\text { de Intangibilidade }\end{array}$} & Empresas & $\begin{array}{c}\text { Média } \\
\text { do } \\
\text { Rank }\end{array}$ & $\begin{array}{c}\text { Soma } \\
\text { dos } \\
\text { Ranks }\end{array}$ & $\begin{array}{l}\text { Mann- } \\
\text { Whitney }\end{array}$ & $\begin{array}{l}\text { Wilcoxon } \\
\text { W }\end{array}$ & Z & $\begin{array}{l}\text { Asymp. } \\
\text { Sig. (2- } \\
\text { tailed) }\end{array}$ \\
\hline \multirow{2}{*}{$\begin{array}{c}\text { Representatividade do } \\
\text { Intangível }\end{array}$} & & 50 & 42,9 & 2146,0 & \multirow{2}{*}{871,00} & \multirow{2}{*}{2146,00} & \multirow{2}{*}{$-2,613$} & \multirow{2}{*}{$0,009 * * *$} \\
\hline & Grupo 2 & 50 & 58,1 & 2904,0 & & & & \\
\hline
\end{tabular}

Nota. $* * *$ Significante a 0,01 .

Fonte: Dados oriundos da pesquisa.

Constata-se pelos dados da Tabela 1, que empresas possuidoras de maior participação relativa de recursos intangíveis em sua estrutura organizacional têm média de representatividade dos ativos intangíveis superior, considerando-se o nível de confiança observável de 99\% (ou Sig. < 1\%), ao de empresas com menor participação relativa do capital intangível. Essa inferência reforça a tese de que os ativos intangíveis são construtores de potencial vantagem competitiva e que, o investidor escolhe pagar valores acima do valor contábil pelas ações dessas empresas. Tomadas todas as especificidades metodológicas consideradas, não se observou evidência que suportasse a rejeição da hipótese H1a.

Neste caso, a informação que indica a preponderância do capital intangível reconhecido pelas firmas brasileiras e divulgado nas notas explicativas do período pode interferir diretamente na percepção do mercado (investidores efetivos e potenciais) que opta pelo desembolso a maior pelos papéis em negociação da empresa com valorização dos ativos intangíveis. Ressalta-se que o efeito percebido aqui, portanto, possui referência pontual ao acréscimo do valor de mercado. Ensejava-se, em meio às inferências demonstradas, verificar se as evidências se estendiam também sobre os desempenhos medidos pelo retorno do capital próprio e do ativo. Os estudos de Villalonga (2004) e Ritta e Ensslin (2010) encontraram reflexos do intangível no valor das empresas e no seu desempenho, o que reforça a construção apresentada. Kayo et al. (2006), além de Teh, Kayo e Kimura (2008), e outros, também defendem o pensamento de que ativos intangíveis são fonte contemporânea da diferenciação entre as empresas modernas.

\subsection{DESCREVENDO A INTERAÇÃO ENTRE GRAU DE INTANGIBILIDADE E O DESEMPENHO}

A última das etapas tomadas por esta pesquisa pertinentes à apresentação do perfil dos ativos intangíveis divulgados em relatórios das maiores companhias abertas brasileiras consistia em 
relacionar grau de intangibilidade e desempenho, este último medido aqui pelos retornos dos acionistas (ou ROE) e dos ativos (ou ROA). Esse relacionamento entre a intangibilidade, os ativos intangíveis ou informação do capital intangível a medidas de desempenho é explorada em alguns estudos (VILLALONGA; 2004; PEREZ; FAMÁ, 2006; TEH; KAYO; KIMURA, 2008; LAURETTI; KAYO; MARÇAL, 2009; LAURETTI, 2011; MENEZES; PONTE; MAPURUNGA, 2013; SALLABERRY, 2014), o que fundamenta a ótica defendida por esta pesquisa. No entanto, anterior à relação sugerida, precisavase caracterizar o desempenho das empresas e isso é consolidado através da Figura 5, onde se traça um contorno dos parâmetros ROA e ROE, especificamente.

Figura 5 - Análise descritiva do desempenho das empresas: ROE e ROA

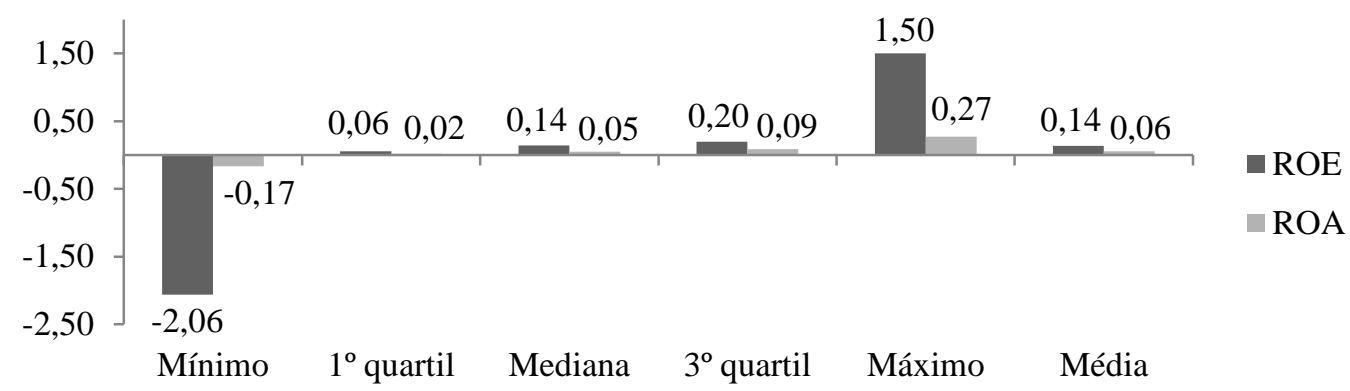

Fonte: Dados oriundos da pesquisa.

As médias de desempenho das empresas em relação a capital próprio e total de recursos aplicados são de $14 \%$ e $6 \%$, respectivamente. Na verdade, metade de todas as empresas têm, no máximo esses resultados (medianas de $14 \%$ e $5 \%$ ). No período abarcado pela pesquisa, $12 \%$ da amostra obteve resultado no período negativo (prejuízo) e assim tiveram seus retornos também negativos. Observou-se que em apenas duas empresas houve um resultado superior à totalidade de seu capital próprio, resultado em valores de ROE em $102 \%$ e $150 \%$. O ROA de melhor desempenho alcançou lucro relativo de $27 \%$ em relação aos ativos totais da empresa.

Em sequência, com o desempenho traçado, à semelhança da manobra tomada na apresentação da Tabela 1, procurou-se comparar as médias de desempenho em confronto com o grau de intangibilidade. Separaram-se os grupos pela mediana (Grupo 1: abaixo; Grupo 2: acima). Por meio da Tabela 2 os resultados dessa análise são apresentados.

Tabela 2 - Desempenho e representatividade do intangível versus a intangibilidade

\begin{tabular}{|c|c|c|c|c|c|c|c|c|}
\hline \multicolumn{2}{|c|}{$\begin{array}{c}\text { Variáveis de Comparação ao } \\
\text { Grau de Intangibilidade }\end{array}$} & Empresas & $\begin{array}{c}\text { Média } \\
\text { do } \\
\text { Rank }\end{array}$ & $\begin{array}{c}\text { Soma } \\
\text { dos } \\
\text { Ranks }\end{array}$ & $\begin{array}{l}\text { Mann- } \\
\text { Whitney }\end{array}$ & $\begin{array}{l}\text { Wilcoxon } \\
\text { W }\end{array}$ & Z & $\begin{array}{l}\text { Asymp. } \\
\text { Sig. (2- } \\
\text { tailed) }\end{array}$ \\
\hline \multirow{2}{*}{ ROE } & Grupo 1 & 50 & 36,5 & 1825,0 & \multirow{2}{*}{550,00} & \multirow{2}{*}{1825,00} & \multirow{2}{*}{$-4,286$} & \multirow{2}{*}{$0,000 * * *$} \\
\hline & Grupo 2 & 50 & 64,5 & 3225,0 & & & & \\
\hline \multirow{2}{*}{ ROA } & Grupo 1 & 50 & 35,6 & 1780,0 & \multirow{2}{*}{505,00} & \multirow{2}{*}{1780,00} & \multirow{2}{*}{$-5,136$} & \multirow{2}{*}{$0,000 * * *$} \\
\hline & Grupo 2 & 50 & 65,4 & 3270,0 & & & & \\
\hline
\end{tabular}

Nota. $* * *$ Significante a 0,01 .

Fonte: Dados oriundos da pesquisa.

Da análise preconizada pela Tabela 2 revela-se que o desempenho, medido nas perspectivas do ROE e do ROA, possui média superior, com significância $<0,01$, em empresas com seu grau de intangibilidade acima da mediana do grupo. Essa evidência corrobora as sinalizações da literatura de que os intangíveis (reconhecidos e não reconhecidos) guardam relação com o retorno das empresas. Com o teste de médias, porém, não se pode esclarecer se o desempenho proporciona melhoria da 
percepção do mercado, ou se a variável intangibilidade em si é um fator construtor do desempenho das firmas. As duas perspectivas têm defesa, visto que, pela primeira lógica, existe uma reação do mercado em alusão à informação disponibilizada pela empresa em seus relatórios contábeis. Em suma, também não se constata evidência a suportar a rejeição da hipótese $H 1 b$, se resguardadas as considerações do método aplicado.

Por fim, para investigar a associação que envolvia o grau de intangibilidade e o desempenho das empresas, procedeu-se com a técnica Anacor. Antes essas medidas foram segmentadas por grupo e transformadas em elementos não métricos (método que viabiliza a Anacor). A separação se deu pelos quartis: a) alto: valor maior que o 3 ㅇ quartil; b) médio-alto: valor entre a mediana e o 3 o quartil; c) médio-baixo: valor maior que o 1 ㅇ quartil e menor que a mediana; e d) baixo: valor inferior ao 10 quartil. Depois de categorizadas, efetuou-se o teste de Qui-quadrado que apontaria ou não existência de dependência entre (i) grau de intangibilidade e ROE e (ii) grau de intangibilidade e ROA.

Tabela 3 - Teste Qui-quadrado

\begin{tabular}{l|c|c}
\hline Associações & N & p-value \\
\hline (i) Grau de Intangibilidade x ROE & 100 & $0,000^{* * *}$ \\
\hline (ii) Grau de Intangibilidade x ROA & 100 & $0,000^{* * *}$ \\
\hline
\end{tabular}

Nota: *** Associações com níveis de significância menor que 0,01.

Fonte: Dados oriundos da pesquisa.

O teste demonstrado na Tabela 3 revelou a dependência entre as variáveis do estudo, com uma significância dentro do limite aceitável (ou $<0,05)$, sugerindo-se ser viável a construção do mapa associativo das medidas. Ordenadamente, a Figura 6 permite compreender como que grau de intangibilidade e ROE estão dispostos em termos de associação. Depois vem a Figura 7 com o mapa associativo do grau de intangibilidade frente ao ROA. Todos os outputs foram devidamente gerados pelo software estatístico SPSS 21.0.

Figura 6 - Mapa perceptual de correspondência: Grau de Intangibilidade x ROE

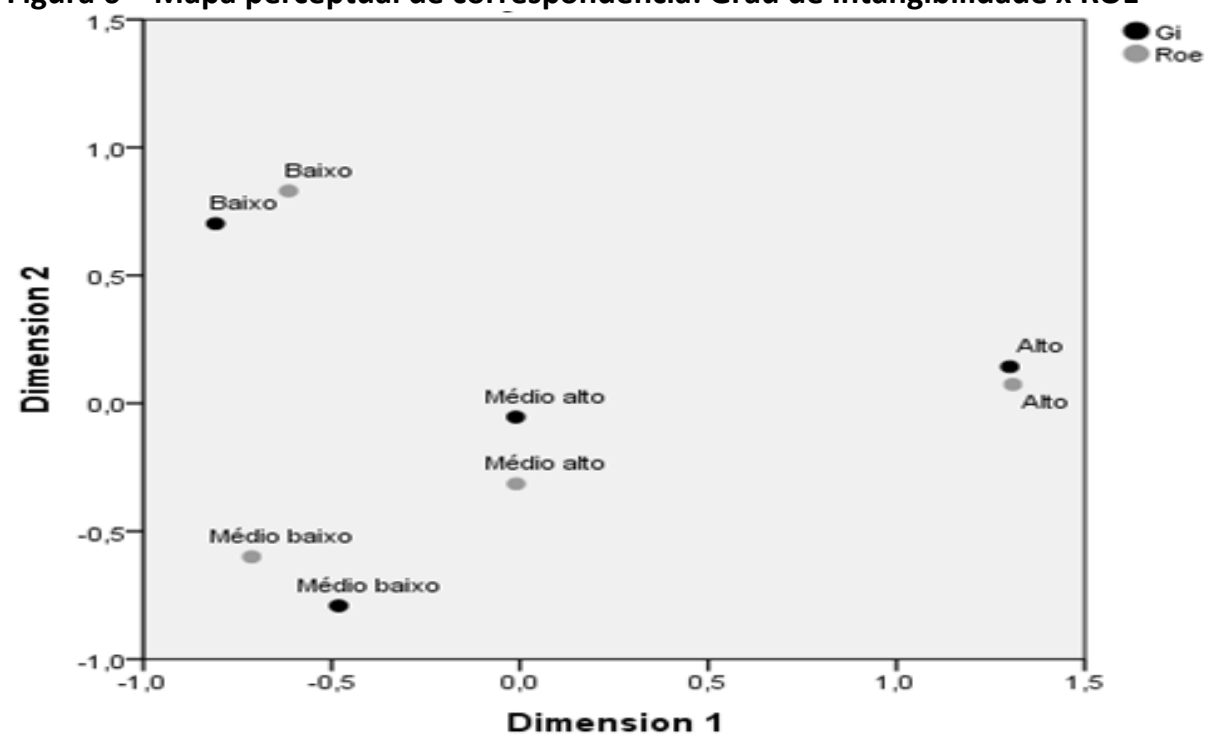

Fonte: Dados oriundos da pesquisa.

O mapa associativo representado na Figura 6 sugere uma dependência positiva entre todas as categorias delimitadas. Verifica-se que altos graus de intangibilidade estão mais associados a um ROE também alto. A correspondência, como observado, é semelhante em todas as demais categorias 
delimitadas: médio-alto, médio-baixo e baixo. Com esses resultados, evidencia-se a dependência entre a intangibilidade (percepção do mercado) e o retorno relativo ao capital que é próprio da empresa (ativos líquidos).

Figura 7 - Mapa perceptual de correspondência: Grau de Intangibilidade x ROA

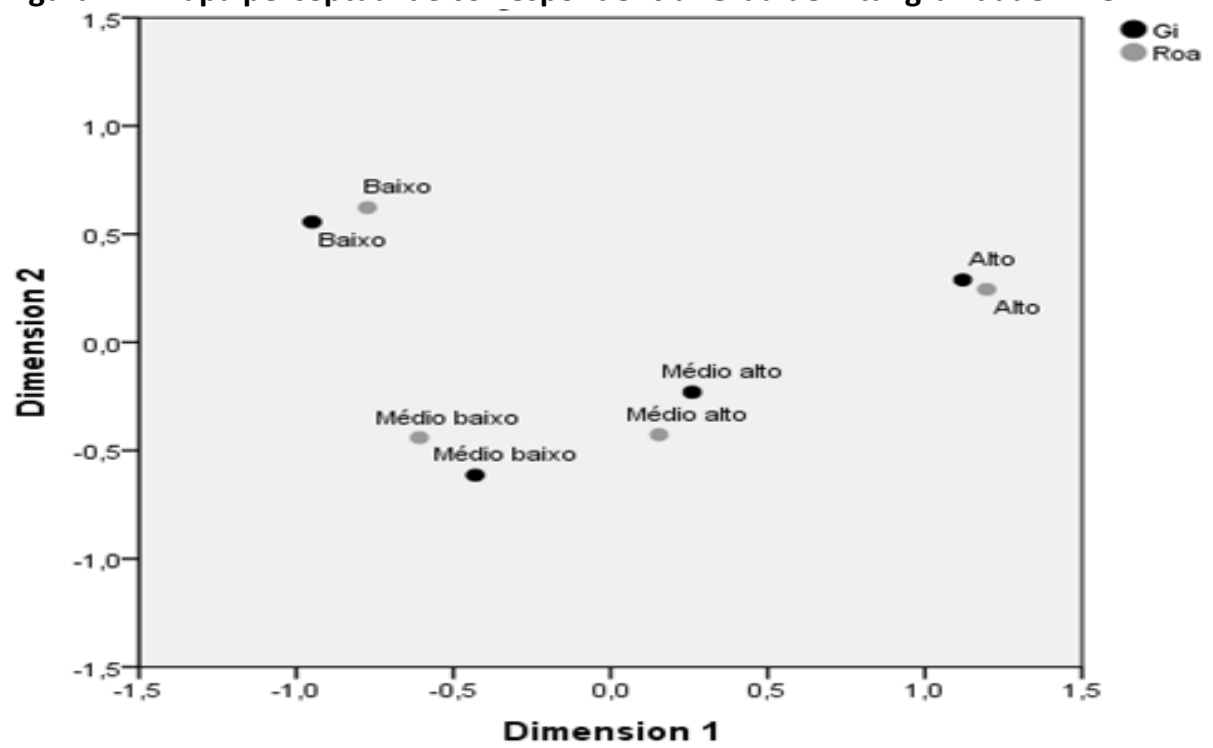

Fonte: Dados oriundos da pesquisa.

De maneira semelhante ao ocorrido na Figura 6, a Figura 7 também sinaliza essa associação positiva entre o grau de intangibilidade e o ROA das empresas. Destarte, deve-se concluir que em empresas com destacada participação relativa do capital intangível em seu patrimônio há, possivelmente, um retorno dos ativos superior. Com as inferências, também não se encontra evidência para rejeição da hipótese H2 levantada. Pensa-se que os ativos intangíveis podem estar corroborando o valor de mercado das firmas brasileiras e, em última instância, por que não, ajudando na consolidação de melhores índices de desempenho (neste caso ROE e ROA). Esses resultados reforçam a lógica de que o ativo intangível e a informação intangível podem sim ajudar na agregação, tanto de diferenciação e competitividade, demonstrada pela literatura pertinente sobre essa discussão.

\section{CONSIDERAÇÕES FINAIS}

O presente estudo alçou como seu objetivo detalhar o perfil dos ativos intangíveis divulgados nos relatórios das maiores companhias abertas brasileiras, considerando-se as prerrogativas da preponderância do recurso no patrimônio da empresa, da identificação das categorias desses ativos, das potenciais relações do investimento aplicado ao capital intangível na valoração da firma atribuída pelo mercado e de sua sensibilidade em relação ao desempenho da empresa.

Esta pesquisa tomou como fundamento de sua realização as diversas sinalizações da literatura sobre uma nova conjuntura corporativa que privilegia o capital idiossincrático das firmas, que é potencialmente capaz de angariar diferentes vantagens competitivas. As empresas modernas têm se tornado investidoras denominadas "intangível-intensivas", porque perceberam que o eixo econômico contemporâneo da criação de valor baseia-se na economia dos intangíveis, e é regida pela aquisição de conhecimento e informação. O contexto brasileiro tende a seguir essa tendência do mercado globalizado, por assim dizer, principalmente após o movimento em prol da convergência às práticas contábeis internacionais, que dentre outras demandas, exigia das empresas a identificação, mensuração, reconhecimento e divulgação dos ativos intangíveis. 
Considerando-se a redução da assimetria informacional como benéfica à liquidez do mercado financeiro, entende-se que a prática contábil da evidenciação do capital intangível favorece a tomada de decisão dos stakeholders, especialmente quando há discrepantes diferenças entre o valor de mercado das firmas e os seus ativos líquidos, sendo essa variação atribuída a todos os intangíveis, identificados e não identificados pela empresa.

O que se observou dentre as evidências, inicialmente, foi o consumo de representativa parcela do conjunto de bens e direitos das empresas pelo capital de natureza intangível, considerando-se a generalidade da média dos investimentos, no grupo avaliado. Esse fato pode demonstrar como as firmas brasileiras têm evidenciado a percepção de valorização do ativo intangível, e por outro lado, as distorções informacionais decorrentes do não reconhecimento destes ativos ou até o seu reconhecimento equivocado em outros grupos patrimoniais. Admitindo-se ser a identificação de todos os intangíveis da empresa, devido às características de idiossincrasia e sinergia dos recursos, pouco provável, a maximização dessa divulgação possui contribuição significativa na tomada de decisão do usuário da informação contábil, não se esquecendo da materialidade da informação intangível negligenciada.

Acerca do arranjo de ativos intangíveis, constatou-se ampla diversificação desses recursos em termos de tipologia. Além do valor investido, o tomador de decisão enxerga a necessidade de conhecer onde os recursos da empresa são direcionados. Essa divulgação corroboraria com o monitoramento dos ativos intangíveis específicos das empresas que aglutinariam às estruturas melhores retornos, por exemplo. Dentro desse escopo, concluiu-se que alguns dos ativos intangíveis possuem representatividade, tratando-se da utilidade às firmas e de investimento alocado. Esses recursos estão, em geral, associados à inter-relação da empresa junto a seus múltiplos agentes econômicos com quem transaciona (clientes, fornecedores, financiadores, e outros). Ressalta-se que o ativo identificado pela aquisição de investimento a maior pelas firmas, em virtude das expectativas de materialização de benefícios econômicos futuros, apresentou maior frequência em relação aos dois quesitos. Ademais, concluiu-se que algumas características das empresas podem sinalizar presença ou utilização de intangíveis na estrutura da firma, conforme prevê a literatura. Alguns ativos intangíveis foram demonstrados apenas em firmas com certa atividade econômica, caso dos bancos analisados.

Os resultados da pesquisa sugerem também que o investimento representativo dos intangíveis reconhecidos pode interferir na percepção do mercado, causando reflexos no valor das firmas. Os investidores compreenderiam que nas organizações com proporção patrimonial intangível majoritária há maior chance de concretização de desempenhos anormais devido às chances de se conseguir vantagens sustentáveis oriundas do capital não tangível. Essa reflexão conclusiva parece ser suportada pelos resultados de diferenças significativas de retorno das empresas em virtude do seu grau de intangibilidade e também pela análise que conclui existir dependência envolvendo as categorias de desempenho e de intangibilidade. Os retornos, do capital próprio e dos ativos das empresas são maiores quanto maior for a diferença entre o valor de mercado e o ativo total líquido. Em suma, nas empresas brasileiras analisadas, os resultados sugerem que os ativos intangíveis podem sim provocar diferenças entre as empresas em questão de retorno, podendo ser essa uma consequência derivada de vantagens competitivas presentes nas firmas consideradas como intangível-intensivas.

Do ponto de vista gerencial, esta pesquisa pode promover estratégias que concentrem esforços das empresas na busca pelo capital intangível capaz de promover a diferenciação e melhores ganhos às firmas, pois são identificados tipos específicos de ativos intangíveis. Por outro lado, ascende no stakeholder a demanda pelo subsídio decisório dotado de valor, oportuno, material e tempestivo - o perfil dos recursos estratégicos da organização. Do prisma teórico, o estudo avançou no debate 
centrado em vantagens competitivas advindas de intangíveis, reconhecidos e não reconhecidos contabilmente, demonstrando que o capital identificado pode impactar os intangíveis não facilmente identificados, depois afetando o desempenho das empresas. Além disso, sugeriu-se uma abordagem amplificada do perfil dos intangíveis, contemplando-se, ao mesmo tempo, quatro diferentes perspectivas do capital intangível das firmas analisadas.

Esta investigação dispõe de inúmeras limitações inerentes ao seu método de pesquisa. Assim, as generalizações de resultados futuros devem levar em conta as especificidades deste estudo, tais como a restrição ao contexto corporativo brasileiro, a não consideração das exigências de divulgação contábil sobre o intangível, a extensão da amostra, bem como o período avaliado com secção temporal única. Sugere-se assim, a priori, a continuidade do estudo em horizonte longitudinal, com a inserção da variável disclosure contábil normativo. Questiona-se também o emprego de demais medidas de desempenho, tais como a criação ou destruição de valor e a oportunidade de crescimento, a fim de se constatarem (ou não) as relações favoráveis do capital intangível em outras searas do desempenho corporativo.

\section{REFERENNCIAS}

ARRIGHETTI, A.; LANDINI, F.; LASAGNI, A. Intangible assets and firm heterogeneity: Evidence from Italy. Research Policy, v. 43, p. 202-213, 2014.

ASSAF NETO, A. Estrutura e análise de balanços: um enfoque econômico-financeiro. 9 ed. São Paulo: Atlas, 2010.

BARDIN, L. Análise de conteúdo. Lisboa: Edições 70, 1977.

BARNEY, J. Firm resources and sustained competitive advantage. Journal of Management, v. 17, n. 1, p. 99-120, 1991.

BASSO, L. F. C.; OLIVEIRA, J. A. S.; KIMURA, H.; BRAUNE, E. S. The impact of intangibles on value creation: comparative analysis of the Gu and Lev methodology for the United States software and hardware sector. Investigaciones Europeas de Dirección y Economía da la Empresa, 2014 (In press). Disponível em: <http://dx.doi.org/10.1016/j.iedee.2014.09.001>. Acesso em: 04. dez. 2014.

CERQUEIRA, D. A. C.; REZENDE, A. J.; DALMÁCIO, F. Z.; SILVA, J. M. O impacto do reconhecimento do custo atribuído e da divulgação de impairment de ativos tangíveis e intangíveis (IFRS) sobre os preços e os retornos das ações das companhias brasileiras. Revista de Contabilidade do Mestrado em Ciências Contábeis da UERJ, v. 17, n. 3, p. 5-23, 2012.

COLAUTO, R. D.; NASCIMENTO, P. S.; AVELINO, B. C.; BISPO, O. N. A. Evidenciação de ativos intangíveis não adquiridos nos relatórios da administração das companhias listadas nos níveis de governança corporativa da Bovespa. Revista Contabilidade Vista \& Revista, v. 20, n. 1, p. 142-169, 2009.

COLLIS, J.; HUSSEY, R. Pesquisa em administração: um guia prático para alunos de graduação e pósgraduação. 2. ed. Porto Alegre: Bookman, 2005.

DECKER, F.; ENSSLIN, S. R.; REINA, D. R. M.; REINA, D. A relação entre os ativos intangíveis e a rentabilidade das empresas listadas no índice Bovespa. REUNA, v. 18, n. 4, p. 75-92, 2013.

FÁVERO, L. P.; BELFIORE, P.; SILVA, F. L.; CHAN, B. L. Análise de dados: modelagem multivariada para tomada de decisões. 4. ed. Rio de Janeiro: Elsevier, 2009. 
HIMMELBERG, C. P.; HUBBARD, R. G.; PALIA, D. Understanding the determinants of managerial ownership and the link between ownership and performance. Journal of Financial Economics, v. 53, p. 353-384, 1999.

KAYO, E. K. A estrutura de capital e o risco das empresas tangível e intangível-intensivas: uma contribuição ao estudo da valoração de empresas. 2002. 110 f. Tese (Doutorado em Administração). Universidade de São Paulo - USP, São Paulo, 2002.

KAYO, E. K.; KIMURA, H.; MARTIN, D. M. L.; NAKAMURA, W. T. Ativos intangíveis, ciclo de vida e criação de valor. Revista de Administração Contemporânea, v. 10, n. 3, p. 73-90, 2006.

KAYO, E. K.; PATROCÍNIO, M. R.; MARTIN, D. M. L. Intangibilidade e criação de valor em aquisições: o papel moderador do endividamento. Revista de Administração da USP, v. 44, n. 1, p. 59-69, 2009.

KUMAR, G. Voluntary disclosures of intangibles information by U.S.-listed Asian companies. Journal of International Accounting, Auditing and Taxation, v. 22, p. 109-118, 2013.

LAURETTI, C. M. A relação entre intangibilidade, desempenho financeiro e desempenho de mercado. 2011. 134 f. Tese (Doutorado em Administração de Empresas). Universidade Presbiteriana Mackenzie, São Paulo, 2011.

LAURETTI, C. M.; KAYO, E. K.; MARÇAL, E. F. A sobrerreação do mercado à informação intangível. Revista Brasileiras de Finanças, v. 7, n. 1, p. 215-236, 2009.

LEV, B. Intangibles: management, measurement, and reporting. Washington: Bookings Institution Press, 2001.

LOW, J.; KALAFUT, P. C. Vantagem invisível: como os intangíveis conduzem o desempenho da empresa. Porto Alegre: Bookman, 2003.

MAZZIONI, S.; RIGO, V. P.; KLANN, R. C.; SILVA JÚNIOR, J. C. A. A relação entre a intangibilidade e o desempenho econômico: estudo com empresas de capital aberto do Brasil, Rússia, Índia, China e África do Sul (BRICS). Advances in Scientific and Applied Accounting, v.7, n.1, p. 122-148, 2014.

MACHADO, J. H.; FAMÁ, R. Ativos intangíveis e governança corporativa no mercado de capitais brasileiro. Revista Contemporânea de Contabilidade, v. 8, n. 16, p. 89-110, 2011.

MENESES, A. F.; PONTE, V. M. R.; MAPURUNGA, P. V. R. Determinantes do nível de disclosure de ativos intangíveis em empresas brasileiras. Revista de Administração e Contabilidade da Unisinos, v. 10, n. 2, p. 142-153, 2013.

PENROSE, E. A teoria do crescimento da firma. São Paulo: Editora da Unicamp, 2006.

PEREZ, M. M.; FAMÁ, R. Ativos intangíveis e o desempenho empresarial. Revista Contabilidade \& Finanças, n. 40, p. 7-24, 2006 a.

PEREZ, M. M.; FAMÁ, R. Características estratégicas dos ativos intangíveis e o desempenho econômico da empresa. Revista Eletrônica de Gestão de Negócios, v. 2, n. 2, p. 69-96, 2006b.

RITTA, C. O.; ENSSLIN, S. R. Investigação sobre a relação entre ativos intangíveis e variáveis financeiras: um estudo nas empresas brasileiras pertencentes ao índice lbovespa nos anos de 2007 e 2008. In: Congresso USP de Controladoria e Contabilidade, 10., 2010, São Paulo, Anais... São Paulo: USP, 2010, p. 1-16.

SAMPIERI, R. H.; COLLADO, C. F.; LUCIO, P. B. Metodologia de pesquisa. 3. ed. São Paulo: McGrawHill, 2013.

SANTOS, J. G. C.; SILVA, L. S.; GALLON, A. V.; DE LUCA, M. M. M. Intangibilidade e inovação em empresas no Brasil. Revista de Administração e Inovação, v. 9, n. 2, p. 197-221, 2012. 
SALLABERRY, J. D. Relação entre os ativos intangíveis e o valor de mercado das empresas brasileiras. 2014. 97 f. Dissertação (Mestrado em Contabilidade). Programa Multiinstitucional e Inter-Regional da Universidade de Brasília - UnB, Universidade Federal da Paraíba - UFPB e Universidade Federal do Rio Grande do Norte - UFRN, Brasília, 2014.

STEWART, T. A. Capital intelectual: a nova vantagem competitiva das empresas. 14 ed. Rio de Janeiro: Elsevier, 1998.

SILVEIRA, A. D. M.; BARROS, L. A. B. C. Determinantes da qualidade da governança corporativa das companhias abertas brasileiras. Revista Eletrônica de Administração, Ed. 61, v. 14, n. 3, p. 1-29, 2008.

SUNDER, S. Teoria da contabilidade e do controle. São Paulo: Atlas, 2014.

TEH, C. C.; KAYO, E. K.; KIMURA, H. Marcas, patentes e criação de valor. Revista de Administração Mackenzie, v. 9, n. 1, p. 86-106, 2008.

TSAI, C-F.; LU, Y-H.; YEN, D. C. Determinants of intangible assets value: the data mining approach. Knowledge-Based Systems, v. 31, p. 67-77, 2012.

VILLALONGA, B. Intangible resources, Tobis's q, and sustainability of performance differences. Journal of Economics Behavior \& Organization, v. 54, p. 205-230, 2004. 